DOI https://doi.org/10.30525/978-9934-26-026-1-1

\title{
CANADA'S DEFENSE AND SECURITY COOPERATION WITH THE EUROPEAN UNION
}

\section{Antokhiv-Skolozdra O. M.}

\section{INTRODUCTION}

Canada's cooperation with the countries of the European continent has experienced long historical tradition. However, it appeared of a rather ambivalent character. It was caused by bipolar structural impact on Canada's search for their own place in international relations, on the one hand, and a gradual development of integrational processes within Europe, on the other. Relocation of the global powers as a result of democratization in Europe provided for widening and deepening of integrational processes, hence, resulting in both - new prospects and restrictions - on realization of Canadian national interests on the global and regional, namely, European, context.

Thus, the beginning of the $21^{\text {st }}$ century was characterized by a gradual restoration of cooperation between Canada and the European Union (hereinafter the EU) after substantial stagnation. During post-bipolar period Ottawa focused on coping with internal issues, while the USA established in the capacity of the key partner on the international arena. Brussels, in its turn, aimed all forces at advancing its own institutions and preparing for the EU's enlargement. Nevertheless, both parties were obliged to reconsider their bilateral relations and seek for the mutually beneficial forms of cooperation. One of the most controversial were the attempts to boost ties in defense and security sphere. Therefore, with the view to gaining better understanding of cooperation between Canada and the EU, we offer the following research in this area.

\section{Preconditions of Canada-EU Security Relations Vector}

Canada's unique contribution to European security, particularly during the Cold War, was based on realizing that the world order is built primarily on military power. At the same time, due to Canada's long-standing underfunding of its armed forces, the gap between the country's official rhetoric and its real military capabilities has widened significantly. The only advantage that the Canadian military still has over its European allies is the ability to deploy troops comparatively quickly, as Canada is able to mobilize a high percentage of its military in a relatively short period.

Another difference between Canada and some European countries is a common understanding of the armed forces' purpose. Based on the established role of an authoritative peacemaker, Canada shares the security 
approaches inherent in most European countries. However, these approaches differ significantly from similar views dominating in the United States. While Europeans seek to make significant efforts in security and defense, Canada does not show clear understanding of which forces to develop primarily: the armed forces or the civilian rapid reaction forces. Thus, the lack of a clear vision of the extent and nature of Canada's involvement in world affairs makes it challenging to determine which security actor it should be and which partners to choose. When small European countries are continually striving to professionalize and specialize their contribution within North Atlantic Treaty Organization (hereinafter NATO) and the EU, Canada has some ambitious security plans that do not match the level of the development of its armed forces ${ }^{1}$.

Canada does not produce defense and security policies. Instead, Ottawa seeks to interpret what it sees as the United States' expectations regarding Canada's actions, tries to secure a shaky internal consensus, and at the same time prevent it from being seen as an "appendage" to Washington. In other words, Canada's security and defense policy is a reflection of its conflicting identity. So Canada has an idea of two or even three security and defense policies, each of which could potentially absorb the country's entire defense budget. P. Martin, in particular, emphasized the following: "being close to the only world power [the United States] instilled in Canadians a sense of pride in our friendly relations and, at the same time, caused desire to determine their own place in the world" 2 .

J. Lindley-French, considering these three dimensions, or varieties of security policy, characterizes them as follows: "Security and Defense Policy $\mathrm{N}$ 1" implies the need for Canada to interact with the United States, given the significant commitments in continental security, in particular through NORAD and significant air forces, as well as through deepening cooperation in the fight against terrorism. "Security and Defense Policy N 2" depicts Canada's determination not to be American, given the need to protect its sovereignty, which requires the presence of the Canadian Navy in the three oceans. "Security and Defense Policy N 3" illustrates Canada's desire to position itself in the world as a "force for good" in terms of participation in humanitarian actions and ensuring stability. All in all, the Canadian strategy is the result of an uncomfortable compromise that has actually led to a "nonstrategy" in the field of defense ${ }^{3}$.

${ }^{1}$ Lindley-French J. Reconnecting Canada to the World (via Europe). International Journal. 2005. N 60 (3). 680 p.

${ }^{2}$ Paul Martin. Foreword from the prime minister: Making a difference. Canada's international policy statement. Ottawa. 2005. 30 p.

${ }^{3}$ Lindley-French J. Reconnecting Canada to the World (via Europe). International Journal. 2005. N 60 (3). 680 p. 
Canada is one of the most protected countries in the world in terms of security issues. Regardless of the nature of its practical steps in this area, the USA, pursuing their own interests, make every effort to protect Canadian space, sovereignty, etc. Obviously, Canada has an interest in a safe environment, though, other countries make a pivotal contribution to its applicable provision. The role of Canadian society is also important in determining Canada's place in the world. Therefore, a Canadian security and defense policy is mostly the result of a complex internal political process. Here we can notice certain analogies with the Europeans, because in Canada there are also voices in favor of asserting its role in the world solely as a "civilian power". However, the effectiveness of such power must be supported by the likelihood of coercion.

From a security and defense perspective, Canadian international affairs involvement can be defined as not very effective. The use of rather limited security capabilities could provide restricted results and lead to marginalized security and defense policy. Nevertheless, all Canadian resources are aimed at preserving, not strengthening, its international position ${ }^{4}$. Canada's strategic uncertainty is also driven by its determination to find a balance between the country's commitments on the American continent and in the world. Unfortunately, the very concept of balance implies a loss of country's direction of its further development. In compliance with its limited financial resources, Canada must show creativity in order to ensure optimal efficiency. It refers to so-called "3D" principle - diplomacy, defense, development, which has been transformed into a holistic security concept ${ }^{5}$. Given the state of the Canadian economy and previous failed attempts to modernize their armed forces, the current starting conditions for their reform can be described as unsatisfactory, especially, if compared to the progress of the USA and the UK. Significant efforts are needed to enable Canada to implement its declared intention to "defend its territory from all threats, protect the northern part of the continent and secure sovereignty, in

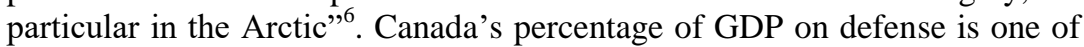
the lowest among the NATO members ${ }^{7}$. Thus, Canadian officials' warnings regarding the European Security and Defense Policy (hereinafter ESDP) about its hypothetical ability to undermine NATO's influence seem rather

${ }^{4}$ Lindley-French J. Reconnecting Canada to the World (via Europe). International Journal. 2005. N 60 (3). 680 p.

${ }^{5}$ Ibid.

${ }^{6}$ Paul Martin. Foreword from the prime minister: Making a difference. Canada's international policy statement. Ottawa. 2005. 30 p.

${ }^{7}$ Lindley-French J. Reconnecting Canada to the World (via Europe). International Journal. 2005. N 60 (3). 680 p. 
ironic. The negative impact on NATO made by other member states that deliberately refuse to invest in the armed forces, is ignored.

Nowadays Canada's strategic uncertainty is driven by two factors. The first one is related to the role of the allies. On the one hand, the United States demand greater involvement of Canada in internal (continental) security. On the other hand, Europeans put some pressure on Canadians as they seek to develop their own security policies. The second factor is the growing incompatibility of Canadian official rhetoric with the country's real potential. This includes its desire to play an essential role in the world due to growth in its military power, however, the policy of S. Harper's government, aimed at increase in financing military sphere, didn't meet its expectations.

Consequently, Canada is forced to look for alternative foreign policy solutions. Primarily, it should focus on four aspects. First of all, Canada must ensure its positive image in the world to meet domestic policy development needs. Secondly, it should increase the influence in relations with the key international players, not only the USA. Thirdly, it has to preserve the dynamics of international alliances with Canada's participation. The fourth aspect refers to its involvement in solving the world's problems. This will ensure Canada's gradual return to the world politics and bring an end to the period of isolation, in particular by renewing its partnership with Europe $^{8}$.

Cooperation between Canada and the EU on the military policy should also be deepened. Not only would this demonstrate its interest in the ESDP, but it also create alternatives to Canada's security commitments. At the same time, some Canadian politicians do not perceive Brussels' steps to develop the ESDP as secondary and detrimental to NATO. However, the development of the EU as an international security player should be assessed as no less important than the implementation of the US defense policy.

Despite its geographical location in North America, Canada's security culture, international security policy, size, organization, and doctrinal support are distinctly "European"9. Moreover, unlike the USA, Canada has always acted and continues to interact with other international players on a coalition terms. Coalition is a European tradition, thus Europe is naturally the ally for Canada. Obviously, relations with the USA will remain a cornerstone of Canada's security policy in the future. It will not have significant leverage in the security sphere: the USA will guarantee continental security, regardless of the nature and extent of Canada's involvement, since it is predominantly the security of the United States

\footnotetext{
${ }^{8}$ Lindley-French J. Reconnecting Canada to the World (via Europe). International Journal. 2005. N 60 (3). 680 p.

${ }^{9}$ Ibid.
} 
itself. In addition, Canadian partners and allies have high expectations for a gradual restoration of Canada's defense capacity after decades of its being a secondary player ${ }^{10}$. Since Europeans regard Canadians as close partners who share values and approaches to conflict resolution, Canada has good prospects for partnership on the international arena ${ }^{11}$. Naturally, Europeans are interested in working more closely with a state, pursuing its foreign policy through international organizations such as the UN and in accordance with generally accepted international principles and norms.

On the one hand, a more integrated North America, whose "cornerstone" is security, serves as a confirmation to Canada's North American identity. On the other hand, the EU, being more integrated in the military and economic dimensions, becomes a challenge for Canadians to see themselves as a "European" nation. A certain paradox is that despite the "European nature" of Canada's key values and the concept of developing its strategic relations based on them, Europeans focus mostly on their own internal problems ${ }^{12}$. Such situation in Canada-EU relations is not fundamentally new. It can be compared to the events of the 1970s, when the question of "contractual relations" was a reaction to the change in the US economic policy and the UK's accession to the EEC. The priorities of Europe were focused on the British integration, in compliance with the economic and foreign exchange market and the difficulties of promoting the integration project in general. Hence, establishing relations with Canada was not effective, especially with regard to security and defense.

\section{Relation Through the Prism of NATO-ESDP Co-existence}

Nowadays prospects of closer relations between Canada and the EU are more promising, in particular, concerning the security and defense sphere. Primarily, in the 1970s, Canada reduced the number of its troops, based in Germany. Although this move was driven largely by economic considerations and its implementation had little impact on the European military balance, the Europeans received a strong argument in the negotiation on Canadian access to the EU market. Thirty years later, 1,200 Canadian troops were stationed in Bosnia as evidence of a ten-year contribution to peacekeeping operations on the European continent. Thus, Canadians played a more important role than most European countries in the Kosovo conflict. Secondly, Canada's defense identity would be tied

${ }^{10}$ Lindley-French J. Reconnecting Canada to the World (via Europe). International Journal. 2005. N 60 (3). 680 p.

${ }^{11}$ Henriques K. This "New Europe": Historic Policy Opportunities for Canada. SIPP Public Policy Paper. 29 January 2005. 140 p.

${ }^{12}$ Pentland C. Odd Man in: Canada and the Transatlantic Crisis. International Journal. 2003/2004. N 59 (1). 172 p. 
exclusively to NATO, as the EU did not focus on military issues. However, since the implementation of the EU CFSP (Common Foreign and Security Policy) in 1993, the European Union has taken serious steps towards the development of the ESDP. Thus, at least the hypothetical existence of a European security identity currently allows Canada to consider security cooperation with the EU as an alternative ${ }^{13}$.

Herewith, Canada's relationship with Europe through NATO doesn't lose its importance. Back in the 1990s, the Canadian government was concerned about NATO's possible decline. Ottawa supported the doctrinal and structural reforms of the Alliance and welcomed its expansion and involvement in the Balkans in 1991-1995, although by analogy with European approaches, it showed restraint on the issue of air attacks ${ }^{14}$. Following the Dayton Accords, Canada's involvement in resolving the conflict in the former Yugoslavia shifted from the UN's to NATO's auspices. One of the most difficult regions in Northern Bosnia belonged to the Canadians' area of responsibility. Canada's involvement in Europe's peace was intended to offset the negative effects of the closure of Canadian military bases on the continent. The 1999 conflict in Kosovo helped strengthen Canada's security presence in Europe in two dimensions. Firstly, the contribution of the Canadian Armed Forces was significant in terms of air attacks on Yugoslavia: the number of Canadian flights, excluding the USA, was the third largest after France and Great Britain ${ }^{15}$. Secondly, some of the U.S. military viewed Canadian involvement as an obstacle to a successful operation, which reaffirmed America's desire for unilateralism and confirmed Canada's European "security profile"16.

Canada's response to the development of the ESDP over the first five years was caused by changes in NATO, Europe itself, and 9/11 events in the USA. Like its European allies, Canada within NATO was a recipient of the US decisions. Canada made attempts to cooperate with the EU after the launch of the ESDP. Ottawa's diplomatic efforts focused on stating that the purpose, structure and processes of the ESDP did not replace or weaken NATO, and ensuring Canada's selective participation in the ESDP. With regard to the former, most reservations were lifted, except for the question of whether European allies will secure their military commitments within

13 Pentland C. Odd Man in: Canada and the Transatlantic Crisis. International Journal. 2003/2004. N 59 (1). 172 p.

${ }^{14}$ Ibid.

${ }^{15}$ Walker S.J. "Interoperability at the speed of sound: Modernizing the cf-i8 Hornet", in David G. Haglund (ed.). Over Here and Over There: Canada-us Defence Cooperation in an Era of Interoperability. Kingston. 2010. 350 p.

${ }^{16}$ Pentland C. Odd Man in: Canada and the Transatlantic Crisis. International Journal. 2003/2004. N 59 (1). 172 p. 
NATO and the ESDP simultaneously ${ }^{17}$. Between 1999 and 2002, Canadian diplomats gained recognition for Canada's involvement in the EU operations within the Petersberg Tasks. It was difficult to achieve and practical implementation has not taken place yet. However, Canada was regarded as a reliable "medium-range" European power with military capabilities to participate in the EU-sponsored operations ${ }^{18}$. Apparently, Canada-EU security cooperation is not limited to the ESDP framework. Since the Maastricht Treaty, especially in fight against terrorism, the EU has made significant progress in cooperating on internal security within one of the "justice and home affairs" pillars. Creating a common space of 28 states requires a number of security issues, including immigration, crime and terrorism. So, the EU is interested in cooperating with such partners as the USA and Canada. The example of this cooperation was the establishment of relations with Europol ${ }^{19}$. The fight against terrorism and international crime has been the basis for further security cooperation strengthening on both sides of the Atlantic Ocean.

In 2005, a National Security Strategy was adopted. That was the first attempt in Canadian history to form a comprehensive government security strategy. It identified three goals: protecting Canadian citizens inside and outside the country; ensuring the security of Canadian territory; strengthening international security. The priority of continental security was set in view of close relations with the United States and efforts to strengthen the southern neighbor in the belief that Canada would not become a "weak link" in its provision. Considerable attention to internal security issues on the continent was driven by some European countries' desire for greater autonomy within NATO. The European Security and Defense Identity is an initiative that gives the EU more freedom of actions in the field of security. While some researchers see it as promising, given the promotion of a "stronger Europe, a more influential NATO, and a healthier and more balanced transatlantic relationship" 20 , others see it as a "violation of NATO's internal procedures and a weakening of Allied cooperation"21. This development attracted attention of Canadian parliamentarians to Canada's place in the new realities. NATO's "Europeanisation" and the

${ }^{17}$ Grant Ch. Security challenges in transatlantic relations. Internationale Politik, 2003. N $4.30 \mathrm{p}$.

${ }^{18}$ Kaim M. Canada warms to ESDP. Internationale Politik. 2003. N 4. 86 p.

19 Potter E. Transatlantic Partners: Canadian Approaches to the European Union. Montreal and Kingston: McGill-Queen's University Press. 1999. 370 p.

${ }^{20}$ Lord Robertson of Port Ellen. The Transatlantic Link, Brussels: North Atlantic Treaty Organization. 2000. 40 p.

${ }^{21}$ Zyla B. A Bridge Just Far Enough: Canada and the Transatlantic Link Today. London Journal of Canadian Studies. 2007-2008. Vol. 23. 210 p. 
development of European security could have serious consequences for Canada: a united and powerful EU would potentially marginalize Canada's role as its geographical location would allow participation only in NATO.

Historically, Europe is considered to be Canada's second most important ally after the United States, due to its economic, cultural, security and political ties. They are united by a regulatory community that creates the preconditions for closer security relations. They have a common normative vision of multilateralism and the need to comply with international law principles. Ottawa and Brussels believe that the use of force is possible only when the possibilities of negotiation and diplomacy are completely exhausted ${ }^{22}$. Canada and the EU share the belief that sustainable development, respect for human rights and peacekeeping should be the key principles in international relations $^{23}$. Likewise, they also worked closely on the establishment of the International Criminal Court (2002) ${ }^{24}$. The Minister for Foreign Affairs of Canada, B. Graham, described the situation as follows: "our vision of the world coincides with our vision of Canada: a projected future with shared security and defense, where tolerance and respect for diversity, democracy and human rights prevail, where opportunities and justice are equal for all"25. Security policy is the area where the differences between Canada and Europe are the most evident. While many common peculiarities in politics and culture remain between the former Franco-British colony and the old continent, and trade relations are high on the bilateral agenda, Canada's status as a power with several thousand troops stationed in Europe between 1952 and 1994 changed to the status of a friendly but distant partner. This was partly due to demographic change in both Europe and Canada. Canadians more often agreed to dependence on the United States and increasingly focused on Asia, while Europeans focused their efforts expanding to the East. The strategic landscape transformations have had a significant impact on Canada-Europe security relations, with Washington playing a key role and European capitals playing a secondary role ${ }^{26}$. Unable to meet its "medium power" demands, Canada has ceased to play a significant role in transatlantic relations.

${ }^{22}$ Agreement between the European Union and Canada establishing a framework for the participation of Canada in the European Union crisis management operations. Official Journal of the European Union. 01/12/2005.L315, 30 p.

${ }^{23}$ Welsh J. Transatlantic Identity and International Action: Rapporteur's Report. Kingston: McGill-Queen's University Press, 2005. 60 p.

${ }^{24}$ Zyla B. A Bridge Just Far Enough: Canada and the Transatlantic Link Today. London Journal of Canadian Studies. 2007-2008. Vol. 23. 210 p.

${ }^{25}$ Henriques K. This "New Europe": Historic Policy Opportunities for Canada. SIPP Public Policy Paper. 29 January 2005. 140 p.

26 Haglund D., Mérand F. Transatlantic relations in the new strategic landscape:Implications for Canada. International Journal. 2010. 150 p. 
Four key issues have dominated transatlantic relations over the last ten years: the transition from territorial defense to the fight against terrorism; creating Europe's security architecture; formatting the balance of forces; strengthening political relations in the transatlantic security community ${ }^{27}$. Herein, today Canada and the EU are focusing on domestic issues. This does not allow them to focus on joint efforts. Improved US-EU relations have reduced Canada's "European character". However, these changes in the strategic interdependence between Europe and Canada do not automatically mean deterioration in the quality of their political, economic or social relations. On the contrary, they can help revitalize cooperation, as sensitive security issues become secondary. In our view, relations between Europe and Canada are, to some extent, a confirmation that a sense of collective identity should not be based solely on common interests.

In spite of the substantial advancement and further consolidation process, especially after the Lisbon Treaty's coming into force, the EU cannot be seen as a homogeneous strategic player today. Besides, the EU has been actively involved in resolving conflicts in sub-Saharan Africa, Asia and the Western Balkans, ignoring its own Eastern European neighbours. Perhaps that is why the EU's security policy is aptly described as a desire to avoid risks.

In this context, it is necessary to focus in more detail on Canada's security role, which is difficult to define unambiguously. In December 2009, at a NATO Ministers meeting, Canadian Foreign Minister L. Cannon spoke in support of Ukraine's and Georgia's membership in NATO. Although the North Atlantic Alliance's official policy remains an open door policy, at that time, Canada stayed, de facto, the only Member State that took this possibility seriously, given the development of Ukraine's and Georgia's situations. For several years, Canada has supported the idea of a "global NATO" involved in extraterritorial missions and aimed at continued expansion. Canada experienced some frustration with the Alliance's concept of being a regional, thus, European player, and it became clear that, it was time to define a more constructive role for NATO in the world ${ }^{28}$. The USA shared the concept of NATO's global role, however, they tried to involve representatives of the EU and Russia in the discussion. Since Canada is not among the nuclear powers and its troops are no longer stationed in Europe, effective involving Canadians in that debate seemed rather weak. However, on many issues, like arms control, human security or the fight against terrorism, Canada and the EU share the

27 Haglund D., Mérand F. Transatlantic relations in the new strategic landscape:Implications for Canada. International Journal. 2010. 150 p.

${ }^{28}$ Ibid. 
same visions, which differ significantly from the US's position. Although the transatlantic dialogue between the EU and Canada is intense, no significant initiatives have been taken in recent years. Canada has participated in a number of the EU police missions, particularly, in Bosnia. However, Ottawa's precarious attempt to find its place in European architecture by signing an agreement in 2005 on Canada's participation in the EU crisis management operations has not been fully implemented due to Canada's attention to Afghanistan and relative indifference of the Conservative governments, starting from $2006^{29}$.

One of the geopolitical realities that are characteristics to relations between Europe and the USA is a certain tension in bilateral relations. In particular, there are some contradictions within NATO, even despite France's return to the military structures of the North Atlantic Alliance. In addition, the US-EU security relations are also ineffective, as the adoption of the Lisbon Treaty did not bring the expected strategic benefits to Washington and did not make the EU a reliable strategic partner.

In this context, it should be noted that despite some differences in researchers' and experts' views, the formation of a new strategic landscape should be considered quite positive and dynamic. The level of differences between states, particularly within NATO, is not critical. Therefore, the North Atlantic Alliance quickly regained its strategic importance, indicating a high degree of its power. This has a direct impact on all transatlantic affairs. As K. Deutsch once stated, the existence of a transatlantic security community is an indisputable fact ${ }^{30}$.

In his turn, V. Pouliot argued, that "the security community is not characterized by the absence of conflicts, and self-evident resolution of them by diplomatic measures"31. It means that in Ottawa there is no need to choose between Washington, London or Paris. However, there is an obvious paradox: good US-EU relations mean that Canada does not have to emphasize its "Europeanism", as in the case of refusing to intervene in Iraq $^{32}$. In the previous strategic context, the confrontation between the US and the EU could be described as manifestations of "anti-Americanism". It was claimed that strengthening of Europe will affect its security and defense role, will not respond to the US interest, and raise the question of

29 Haglund D., Mérand F. Transatlantic relations in the new strategic landscape:Implications for Canada. International Journal. 2010. 150 p.

${ }^{30}$ Ibid.

${ }^{31}$ Pouliot V. The alive and well transatlantic security community: A theoretical reply to Michael Cox. European Journal of International Relations. 2006. Vol. 12, N 1. 150 p.

${ }^{32}$ Haglund D., Mérand F. Transatlantic relations in the new strategic landscape: Implications for Canada. International Journal. 2010. 150 p. 
setting Europeans free from American "guardianship" 33 . Some even stated that Europe could become an American rival. However, these predictions did not come true. Despite claims about the "selective participation" of Canada in European conflicts, this country was forced to take active action. If the problem of Canada's participation in European conflicts provoked internal confrontation, non-participation could lead to a split within the state. At that time, Europe was of strategic importance to Canada, as Canada was regarded as a "European land" 34 .

From Canada's security perspective, currently the EU, despite becoming a homogeneous actor, is gaining an "optional" stance. Ottawa shows little interest towards establishing a European security architecture. However, common values, that will not disappear in the future, are likely to bring Canadians and Europeans closer to the United States, China and India, leaving space for security cooperation. Its effectiveness will depend on whether both sides find common ground on economic governance and climate change.

Following the meeting in Saint-Malo, the Canadian government was cautious towards the development of the $\operatorname{ESDP}^{35}$. On the one hand, public declarations emphasized the need for the EU to take security responsibility in the Europe. However, these calls always meant that the ESDP would not threaten transatlantic relations. In December 2003, the Minister of Defense expressed his concern about the ESDP ${ }^{36}$ : "Canada welcomes the ESDP as a new instrument for crisis management. However, we believe that the ESDP should be implemented in a way that does not shake the transatlantic alliance, it being a key institution for cooperation and joint action in the field of Euro-Atlantic defense and security"37. As S. MacFarlane pointed out, Canada's response to the ESDP should regard a number of factors ${ }^{38}$. First of

${ }^{33}$ Walker S.J. "Interoperability at the speed of sound: Modernizing the cf-i8 Hornet", in David G. Haglund (ed.). Over Here and Over There: Canada-us Defence Cooperation in an Era of Interoperability. Kingston. 2010. 350 p.

34 Haglund D., Mérand F. Transatlantic relations in the new strategic landscape:Implications for Canada. International Journal. 2010. 150 p.

35 Fortmann M., Viau H. Le Canada et la Politique européenne de sécurité et de défense. Une politique à la croisée des chemins. Revue internationale et stratégique. 2001. $\mathrm{N} 44$ (4). 70 p.

${ }^{36}$ McCallum J. Sur le success que connait L'OTAN en matiere d'etablissement de la paix et de stabilite, de meme que sur les repercussions de ces facteurs sur l'avenir de l'Alliance. URL: $\quad$ http://www.forces.gc.ca/fr/nouvelles/article.page?doc=john-mccallum-prononce-undiscours-devant-les-membres-de-la-royal-institute-of-international-affairs/hnocfjkw

${ }^{37}$ Morel J. Le Canada, l'Otan et la politique Européenne de sécurité et de defense. Politique étrangère du Canada. 2007. N 14 (1). 150 p.

${ }_{38}$ MacFarlane S. Canada and the "European Pillar" of Defence: What NATO for Canada? Kingston: Centre for International Relations. 2000. 70 p. 
all, due to Canada's long history of involvement in the defense and security in Europe, during the two world wars, the Cold War, and the conflict in the former Yugoslavia, Canadians demonstrate that Europe was and remains important for Canadian security interests. Therefore, the ESDP should not be the reason for the loss of the historical ties, uniting Canada and Europe.

Canada's response to the ESDP was the country's efforts to ensure that NATO's leadership be maintained, which was to remain a key organization in Europe's collective defense and to retain the "supremacy" right in case of intervention. Herewith, Canadian and American concerns coincided: NATO member states, non-members to the EU, had to retain the right to speak on European security issues. Nevertheless, according to Canadian leadership, the right of "supremacy" for NATO was not sufficient. After all, the ESDP could contribute to the formation of a separate "European faction" within NATO, which would consist exclusively of the EU members. Such developments could hamper the decision-making process within NATO, which is adopted by consensus. Moreover, such a "European faction" could interact directly with the United States on key decisions. Thus, Canada's importance within NATO would be completely marginalized ${ }^{39}$.

Another irritating factor for Canada was the decision on applying the EU's NATO military forces to conduct its own operations. Canada insisted on precise consultation mechanisms that would allow the country to participate in strategic planning for the EU's application of NATO's military forces (since Canadian troops could also be involved in European operations) and participate in the ESDP operations when necessary. To ensure the strength of transatlantic relations, Canada was interested in providing the ESDP link to NATO. The Canadian government headed by J. Chrétien was concerned that a report submitted to the EU Council in Feira (2000) identified Russia and Ukraine as potential partners in the EU operations. In contrast, Canada was described as the one interested in the ESDP. Ottawa's desire to work closely with the EU in the framework of the ESDP prompted the adoption of a "Joint EU-Canada Declaration on Security and Defense" in December 2000. This document is regarded a victory for Canadian diplomacy, since the EU recognizes that NATO remains the mainstay of Member States' collective defense and agrees to deepen the dialogue with Canada on its participation in the ESDP. In practice, it provided the regular bilateral meetings on the level of experts, during which a set of defense and security issues of mutual concern to Canada and the EU were to be conducted ${ }^{40}$.

${ }^{39}$ Morel J. Le Canada, l'Otan et la politique Européenne de sécurité et de defense. Politique étrangère du Canada. 2007. N 14 (1). 150 p.

${ }^{40}$ Eu-Canada declaration on the ESDP. URL. http://www.canadainternational.gc.ca 
In June 2002, the EU Council adopted provisions on the EU-Canada cooperation, including agreement that the parties would address security and defense issues in existing bilateral fora, at the level of Heads of State and Government and relevant ministers. Canada would personally decide on its participation in the EU military operations, not only when it applies NATO's "Berlin Plus" capability, but also when the EU conducts its procedures. Following the provisions adopted in Seville, Canada participated in planning the operations. To this end, Canada gained the opportunity to appoint a representative to the EU General Staff. Due to these arrangements, Canada had the right to participate in the EU - sponsored military and civilian activities under the ESDP, including Operation Artemis in the Democratic Republic of Congo, operations in Bosnia and Herzegovina. Besides, the legal basis for Canada's participation in the EU operations, later included in the bilateral framework agreement, was worked out. Negotiations were concluded during the EU-Canada summit in Niagara in May 2005. The signing of a Framework Agreement on this issue took place on 24 November $2005^{41}$.

Notwithstanding, signing the Framework Agreement took place at the time when a number of issues, raising Canada's reservations towards the ESDP, were not relevant. In 2000 McFarlane claimed that the Canadian government considered security and stability as priority in Europe and sought to remain involved in peacekeeping decisions in the Balkans (Canada participated in the NATO-supervised war in Kosovo and had a Canadian contingent SFOR in Bosnia and Herzegovina). Upon concluding the Framework Agreement, these threats and needs became irrelevant. Of course, it does not mean that Canada lost its interest in stability and peace on the European continent, but the key to security in Europe was the EU and NATO's enlargement. In this context, Ottawa was able to limit itself to supporting Central and Eastern European countries' membership in NATO. Canada also monitored the situation in Kosovo, but since 2000, Canadian soldiers have ceased to be part of KFOR, and the presence in the Balkans was limited to the symbolic presence of Canadian troops in EUFOR in Bosnia. Although Canada considers the issue of stability in Europe important, it does not consider this issue appropriate for increasing military presence on the continent ${ }^{42}$.

${ }^{41}$ Agreement between the European Union and Canada establishing a framework for the participation of Canada in the European Union crisis management operations. Official Journal of the European Union. 01/12/2005.L315, 30 p.

${ }^{42}$ Morel J. Le Canada, l'Otan et la politique Européenne de sécurité et de defense. Politique étrangère du Canada. 2007. N 14 (1). 150 p. 


\section{Cooperation in the Realities of the New Century}

Following the terrorist attacks of 9/11, the fight against terrorism was regarded as a key area of Canada's security and defense. According to D. Haglund, in pursuance to economic, political, cultural and historical reasons, Canada was seen within NATO as the country most affected by the terrorist attacks (after the US) ${ }^{43}$. Since October 2001, Canada became one of the first countries to join the US anti-terrorist coalition against the Taliban regime in Afghanistan and eliminate the Alkaida network. Since then, rebuilding Afghanistan became Canada's key foreign policy challenges. In August 2003, Canada got chairmanship in the International Security Assistance Force (ISAF), it playing a key role in making it a full-fledged NATO mission. One of the key provinces, Kandahar, was of Canada's responsibility. The Harper Conservative government, which came to replace Martin's Liberal government, supported Canada's participation in Afghanistan's 2006 mission ${ }^{44}$. Therefore, Canada has played a key role in the Alliance in the context of the 9/11 events, particularly given its presence outside the traditional area of responsibility. From a Canadian perspective, NATO's involvement in tackling terrorism became a turning point in the Alliance's history. According to Canada, the current NATO is a community, sharing democratic values and a forum for influencing transatlantic relations. Consequently, the geographical expansion of the Alliance's sphere of influence confirmed its value in the eyes of the Canadian leadership. In addition, owing to Canada's contribution to ISAF in Afghanistan, the country managed to maintain its top importance within NATO.

Therefore, the ESDP issue rises fewer concerns in Ottawa today, especially given the transformation of the EU-NATO relations. The current state of the ESDP does not in any way threaten NATO's leadership, and the "Berlin Plus" Agreement guarantees NATO the "right of supremacy", which used to be of a particular concern to Canadian politicians. For the same reasons, fears that the ESDP could lead to the emergence of a "European faction" within NATO have also lost relevance ${ }^{45}$.

It should be noted, that the signing of the Framework Agreement (2005) did not indicate a significant rapprochement between the EU and Canada in the field of defense. Of course, the Canadian government would consider Canada's participation in ESDP operations if necessary, but its involvement in the Afghan issue is more indicative of the minimal or

${ }^{43}$ Haglund D., Mérand F. Transatlantic relations in the new strategic landscape: Implications for Canada. International Journal. 2010. 150 p.

${ }^{44}$ Morel J. Le Canada, l'Otan et la politique Européenne de sécurité et de defense. Politique étrangère du Canada. 2007. N 14 (1). 150 p.

${ }^{45}$ Ibid. 
symbolic Canada's involvement in European affairs, as was the case with EUFOR (Bosnia). However, Canadian Deputy Foreign Minister P. Harder expressed hope that the ESDP would play a complementary role to NATO's efforts, as the Alliance remains a key forum for transatlantic security and defense cooperation for Ottawa. P. Harder stressed the relevance of NATO's transformation and the need to move away from geographical constraints. "Does NATO need soldiers and military bases on European territory?" he asks. Canada answered it in the early 1990s by closing its military bases in Europe. After that, the implementation of the strategy of reforming our (Canadian) armed forces started so that they meet the challenges of the present, not the past. "This statement demonstrates the lack of European priority on Canada's security list. Therefore, Canada's involvement in the ESDP can only be partial"46. Canada's policy towards Europe was often characterized by "short periods of over-enthusiasm, followed by periods of inactivity" 47 . The same can be said of the ESDP. With the inception of the ESDP, Canada found the concept appealing, however, later lost interest in it. It can be explained by various factors: the insignificant progress of the ESDP itself, the changes that have taken place within NATO and the role that Canada has played in the transformation of the North Atlantic Alliance, etc. It is unlikely that Canada will actively participate in ESDP-led missions in the near future. Some experts believe this step to be irrelevant, because refusing to participate in security cooperation with the EU is an attempt to deny Canada's strategic culture, which is closer to Europe than to the USA. Nevertheless, this issue is of interest only to a small circle of politicians and researchers, so it remains out of the attention of Canadian society.

Without elaborating on the issue of European governance, it should be noted that Canada maintains relations with the EU according to the Westphalian system principles. Therefore, Canadian diplomacy treats the EU as a state with bilateral relations. The Canadian military seek to cooperate directly with member countries through NATO, as if the EU did not exist.

From a political or diplomatic perspective, it should be noted that there is a close network of contacts between Ottawa and Brussels. Following a long rapprochement based on economic cooperation since the Framework Agreement (1976), the Transatlantic Declaration (1990) laid the groundwork for an intensive political dialogue involving a regular summit between the

\footnotetext{
${ }^{46}$ Morel J. Le Canada, l'Otan et la politique Européenne de sécurité et de defense. Politique étrangère du Canada. 2007. N 14 (1). 150 p.

${ }^{47}$ Buteux P. Canada and Europe: The Implication of the Common Foreign and Security Policy: Between Actor and Presence: The European Union and the Future far the Transatlantic Relationship. Ottawa: University of Ottawa Press. 2001. 125 p.
} 
Prime Minister and the EU. Ministers of Foreign Affairs and Trade also meet two to four times a year ${ }^{48}$.

To support this dialogue, the Ministries of Foreign Affairs and Trade and their partners in Brussels have implemented a consultation system since 1996 in line with the EU-Canada Action Plan. Therefore, once or twice a year, those responsible for certain policy areas or regional issues meet to discuss current problems. There are also regular meetings of the Canadian representative to the EU with representatives of the Political and Security Committee of the Council of the EU in the framework of political consultations between Canada and the European Union. A substantial element of the consultations is the meetings of the Head of the Political Department of the Ministry of Foreign Affairs of Canada with the representatives of the European Commission, the Council of the EU and the representative of the chair state, which take place every six months. Canada prefers cooperation with individual EU member states, such as Germany or France, but this cooperation seems insufficient given the large-scale cooperation with the USA, where interaction gained institutionalized forms, such as NORAD, the Bilateral Planning Group, Canadian-American Committee on Military Cooperation. Close cooperation between Americans and Canadians also take place within NATO. As a result, it has strengthened the Atlanticist traditions in the Canadian Department of Defense.

Lacking in sufficiency, the EU-Canada defense consultation system is a kind of demonstration of inconsistency with the provisions of the Joint Declaration adopted in 2000, which gave Canada an important role in the Contributors Committee, a forum for consulting third countries in the EUsponsored operations. However, in accordance with Canadian diplomats, this was not enough and they insisted that Canada should have the same rights under the ESDP as European countries, non- members of NATO at the time. However, given the EU's inertia and the lack of support from the Canadian military, the diplomats' efforts proved to be vain ${ }^{49}$. During the 2005 summit in Niagara, the Prime Minister of Canada, P. Martin, and his European partners stressed the importance of the Framework Agreement for Joint Operations. The idea of signing it was supported by Canadian and European diplomats, while representatives of the Canadian General Staff opposed its conclusion, believing that it would bring additional complications $^{50}$.

${ }^{48}$ Mérand F. Les nouvelles relations transatlantiques en matière de défense: quel rôle pour le Canada? Politique étrangère du Canada. 2005. N 12 (2). 148 p.

${ }^{49}$ Ibid.

${ }^{50}$ Ibid. 
In its official rhetoric, Canada claims to be committed to internationalism principles in the field of security, but in view of its financial capabilities, it is rather isolationism. Therefore, despite the importance of Canada's place in the security sector, the question of Ottawa's ability to engage in high politics with a "low" budget remains open". Nowadays, relations between the EU and Canada are characterized by high intensity at the diplomatic level, which, however, is not continued in the strategic-military sphere. Canada's defense policy focuses on bilateral cooperation with the United States and NATO. While Ottawa is aware of the growing importance of the EU's security and defense role, it is responding to this through traditional bilateral channels (privileged relations with the USA and the UK) and the transatlantic format.

To influence the ESDP, Canada needs to have its own institutional presence there. The Contributors Committee, which Canada was optimistic about, proved ineffective. On the other hand, Canada sought and was able to have a representative on the ESDP planning authorities, but later lost interest in doing so. Today, Canada does not even have a military attaché to the $\mathrm{EU}^{52}$. Some EU member states have a negative attitude towards the third countries participation in the ESDP, especially when it comes to Canada, which is outside the European continent. According to their leadership, this could erode the decision- making process within the EU and undermine its autonomy.

In this context Agreement on Strategic Partnership between the EU and Canada, signed in September 2014, is significant ${ }^{53}$. The document states that both Parties shall make attempts to strengthen transatlantic security with the due role of the current central security structure. Thus, the initial significance of NATO is defined. Another important element is recognizing the necessity of close cooperation between Canada and the EU concerning resolving crisis situations, particularly, under the EU supervision. The key characteristics of the Agreement is the need for multilateralism in solving numerous security issues.

${ }^{51}$ Buteux P. Canada and Europe: The Implication of the Common Foreign and Security Policy: Between Actor and Presence: The European Union and the Future far the Transatlantic Relationship. Ottawa: University of Ottawa Press. 2001. 125 p.

${ }^{52}$ Mérand F. Les nouvelles relations transatlantiques en matière de défense: quel rôle pour le Canada? Politique étrangère du Canada. 2005. N 12 (2). 148 p.

53 Strategic Partnership Agreement between the European Union and its Member States, on the one part, and Canada, on the other part. URL: http//eur-lex.europa.eu/legalcontent/EN/TXT/?uri=JOIN:2015:10:FIN 


\section{CONCLUSIONS}

In the view of their common long history of mutual relations, the potential of the EU-Canada cooperation has been used only partly. Canadian policy towards the EU has never been consistent, while the EU police towards Canada gained the secondary meaning due to priority to the relations with the USA. However, the interconnection between Canada and the USA has been sustainable. The more Canada is integrated with the USA, the less significant it becomes in other parts of the world. That is why the opportunity to intensify its relations with the EU is primarily important.

Security culture of Canada and peculiarities of conducting the defense policy are distinctly "European". Europe is the second important ally for Canada after the USA due to their close economic, cultural, security and political ties.

It should be noted that for a long time security cooperation has not been limited only by military actions. Ottawa and Brussels pay close attention to new security challenges, which was reflected in the Agreement on Strategic Partnership. After the 9/11 attacks in 2001 Canada and the EU intensified their cooperation against terrorism. Thus, in the Agreement on Strategic Partnership (2014) the emphasis is made on the necessity to strengthen mutual anti-terrorist initiatives and cooperation through existing mechanisms of consultations, exchange of information and common activity within multipartite institutions such as the Global anti-terroristic forum.

Terroristic threats caused the necessity for closer cooperation in the law and security sphere, as well as coordination of efforts in combatting small security challenges. Besides, intensified cooperation emerged due to the new threats of the $21^{\text {st }}$ century. It concerns cyber-crimes, organized crime, drug trafficking, corruption and others. Unfortunately, on the list of the new threats are the military interventions, in particularly, in Crimea and in the East of Ukraine by Russian Federation. Unlike its partners, Canada took uncompromised position in this issue. Today it is still early to estimate the future development of the EU-Canada's relations, however, all these challenges are on the agenda of their mutual relations in the security sphere. Following the gained experience and common values, Canada and the EU are likely to cooperate in solving social problems and facing the global challenges.

\section{SUMMARY}

The article deals with the peculiarity of establishing and developing relations between the EU and Canada in security sphere. It observes the establishment of cooperation between Canada and the EU after introducing the European policy of security and defense. 
In particular, it defines that the Canadian Government accepted the fact of strengthening the security part of the EU activity in a reserved manner, as it could cause decrease in influence of this North American State in EuroAtlantic area. It outlines the main directions of cooperation, scrutinizes institutional mechanisms of interaction and emphasizes the key challenges of security dimension of bilateral relations. It deals with the peculiarities of Canada's participation in military and civil actions under the auspices of the EU and stresses that the limited military potential of Ottawa makes its effective participation in bilateral cooperation with the European partners less possible. It stresses the priority in relations between Canada and the USA in security sphere and underlines the significant role of NATO in its interaction on the security and defense issues between Canada and the European Union. It emphasizes that the official Ottawa insists on NATO playing the leading role in providing security in Euro-Atlantic area. It depicts that Canada and the EU have started developing cooperation outside ESDP on domestic security, in particular, on struggle against organized crime and other challenges of current society, which has encouraged institutionalization in relationship of the European Union and the Europol.

\section{REFERENCES}

1. Agreement between the European Union and Canada establishing a framework for the participation of Canada in the European Union crisis management operations. Official Journal of the European Union. 01/12/2005.L315, $30 \mathrm{p}$.

2. Borinski Ph., Fear of alternative outcomes: NATO and European security cooperation. Contemporary Security Policy. 2002. N 23. 130 p.

3. Buteux P. Canada and Europe: The Implication of the Common Foreign and Security Policy: Between Actor and Presence: The European Union and the Future far the Transatlantic Relationship. Ottawa: University of Ottawa Press. 2001. 125 p.

4. David Ch.-Ph. Le Canada et le système de sécurité européen. Défense nationale. 1996. N 52 (2). 70 p.

5. Donneur A. La fin de la guerre froide: le Canada et la sécurité européenne. Études internationals. 1992. N 23 (1). 145 p.

6. EU-CANADA DECLARATION ON THE ESDP. URL: http://www.canadainternational.gc.ca

7. Fortmann M., Viau H. Le Canada et la Politique européenne de sécurité et de défense. Une politique à la croisée des chemins. Revue internationale et stratégique. 2001. N 44 (4). 70 p.

8. Godement F. A global China policy. Policy Brief, European Council on Foreign Relations, London. June 2010. URL: http://ecfr.eu/page//documents/A-global-China-policy.pdf 
9. Grant $\mathrm{Ch}$. Security challenges in transatlantic relations. Internationale Politik, 2003. N 4. 30 p.

10. Haglund D., Mérand F. Transatlantic relations in the new strategic landscape:Implications for Canada. International Journal. 2010. 150 p.

11. Henriques K. This "New Europe": Historic Policy Opportunities for Canada. SIPP Public Policy Paper. 29 January 2005. 140 p.

12. Kaim M. Canada warms to ESDP. Internationale Politik. 2003. N $4.86 \mathrm{p}$.

13. Lindley-French J. Reconnecting Canada to the World (via Europe). International Journal. 2005. N 60 (3). 680 p.

14. Lord Robertson of Port Ellen. The Transatlantic Link, Brussels: North Atlantic Treaty Organization. 2000. 40 p.

15. McCallum J. Sur le success que connait L'OTAN en matiere d'etablissement de la paix et de stabilite, de meme que sur les repercussions de ces facteurs sur l'avenir de l'Alliance. URL: http://www.forces.gc.ca/ fr/nouvelles/article.page?doc=john-mccallum-prononce-un-discours-devantles-membres-de-la-royal-institute-of-international-affairs/hnocfjkw

16. MacFarlane S. Canada and the "European Pillar" of Defence: What NATO for Canada? Kingston: Centre for International Relations. 2000. 70 p.

17. Mérand F. Les nouvelles relations transatlantiques en matière de défense: quel rôle pour le Canada? Politique étrangère du Canada. 2005. N 12 (2). 148 p.

18. Morel J. Le Canada, l'Otan et la politique Européenne de sécurité et de defense. Politique étrangère du Canada. 2007. N 14 (1). 150 p.

19. Pentland C. Odd Man in: Canada and the Transatlantic Crisis. International Journal. 2003/2004. N 59 (1). 172 p.

20. Paul Martin. Foreword from the prime minister: Making a difference. Canada's international policy statement. Ottawa. 2005. 30 p.

21. Pouliot V. The alive and well transatlantic security community: A theoretical reply to Michael Cox. European Journal of International Relations. 2006. Vol. 12, N 1.150 p.

22. Potter E. Transatlantic Partners: Canadian Approaches to the European Union. Montreal and Kingston: McGill-Queen's University Press. 1999. $370 \mathrm{p}$.

23. Risse-Kappen Th. Cooperation among Democracies: The European Influence on US Foreign Policy. Princeton: Princeton University Press. 1995. $265 \mathrm{p}$.

24. Strategic Partnership Agreement between the European Union and its Member States, on the one part, and Canada, on the other part. URL: http//eur-lex.europa.eu/legal-content/EN/TXT/?uri=JOIN:2015:10:FIN

25. Martin Walker. Bush's choice: Athens or Sparta. World Policy Journal. 2001. N 18. 135 p. 
26. Walker S.J. "Interoperability at the speed of sound: Modernizing the cf-i8 Hornet", in David G. Haglund (ed.). Over Here and Over There: Canada-us Defence Cooperation in an Era of Interoperability. Kingston. 2010. $350 \mathrm{p}$.

27. Welsh J. Transatlantic Identity and International Action: Rapporteur's Report. Kingston: McGill-Queen's University Press, 2005. $60 \mathrm{p}$.

28. Zyla B. A Bridge Just Far Enough: Canada and the Transatlantic Link Today. London Journal of Canadian Studies. 2007-2008. Vol. 23. $210 \mathrm{p}$.

Information about the author: Antokhiv-Skolozdra O. M., Candidate of Political Science, Associate Professor at the Department of International Relations and Diplomatic Service Ivan Franko National University of Lviv 1, Universytetska str., Lviv, 79000, Ukraine 